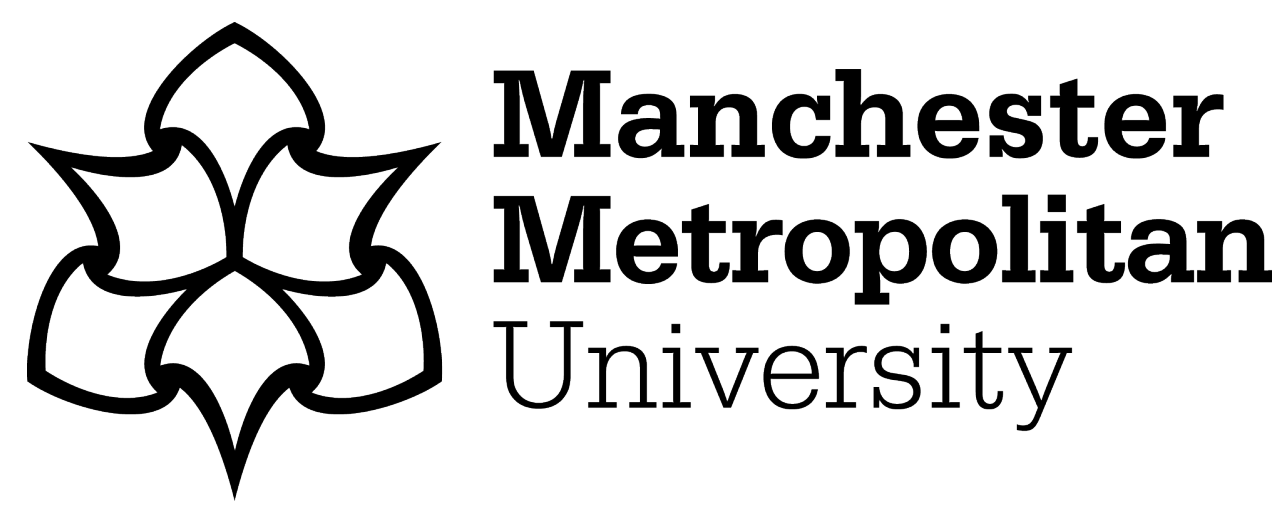

Kubacki, K and Skinner, H (2006) Poland: Exploring the relationship between national brand and national culture. Journal of Brand Management, 13 (4-5). pp. 284-299. ISSN 1350-231X

Downloaded from: https://e-space.mmu.ac.uk/621224/

Version: Accepted Version

Publisher: Palgrave Macmillan UK

DOI: https://doi.org/10.1057/palgrave.bm.2540272

Please cite the published version 


\title{
Poland: exploring the relationship between national brand and national culture
}

\author{
Krzysztof Kubacki and Heather Skinner \\ University of Glamorgan \\ Trefforest \\ Rhondda Cynon Taff \\ CF37 1DL
}

Corresponding author E-mail: hskinner@glam.ac.uk 


\title{
Poland: exploring the relationship between national brand and national culture
}

\begin{abstract}
This research aims to identify the essence of the Polish national brand and the way Polish culture is being communicated through the national brand. Having conducted both quantitative and qualitative research into the cultural symbols of the nation and their representations within and outside of Poland, findings evidence a discrepancy between what is perceived as the nation brand within Poland, the way the brand is communicated, and the way the brand is perceived outside of the country. The paper concludes with some reflections upon the relationship between national brand and national culture, and how that could be better managed.
\end{abstract}

\section{The roots of national brand in national culture}

Studies into perceptions of national identity are closely associated with studies of the culture of a nation (Gellner, 1983; Anderson, 1991). From the Latin cultura, "Cult ... means to inhabit, till or worship and are is defined as 'the result of'; thus in the broadest sense, one might define culture as ‘the result of human action’ (Berthon, 1993)”, (Warner and Joynt, 2002). With such an all-encompassing definition, studies of national identity are to be found across a wide range of academic disciplines including marketing, tourism, sociology, anthropology, and comparative management, all of which offer various perspectives on studies that relate to culture and nationhood.

\section{National brand}

The argument that places can indeed be branded has few dissenters, although those that there are tend to generate "violent reactions" and "visceral antagonism" to the whole concept (Olins 2002). Morgan, Pritchard and Pride (2002) claim that many academics have "shied away" from entering the debate, "arguing that places are too complex to include in branding discussions since they have too many stakeholders and too little management control, have underdeveloped identities and are not perceived as brands by the general public". However, Hankinson (2004) notes that 
"the branding of places is now widespread", and Morgan, Pritchard and Pride (2002) have found that amongst those responsible for marketing places, "destination branding is one of today's 'hottest' topics" with Papadopoulos (2002) finding more than 750 major publications in the last 40 years or so on the broad subject. With around 191 nations in the world competing internationally for market share in tourism, inward investment and export, it is Kotler and Gertner's (2002) belief that nations with a strong positive brand identity will be able to gain competitive advantage in such a global marketplace over those nations that have a poorly developed identity, or those whose brand identity is perceived as negative. When communicating that national brand to the world, Kotler and Gertner (2002) believe that "to be effective, the desired image must be close to reality, believable, appealing and distinctive (there are already too many 'friendly places' out there)”. Kotler and Gertner believe that the national brand is communicated through a nation's geography, history, proclamations, entertainment industry and media, art and music, its famous citizens and other features. Anholt (2002), a leading author on place branding, believes that a national brand is communicated through a nation's culture, language, its creative arts, images of popular culture, tourism and travel writing and its commercial branded products. He has called for research into a number of underdeveloped areas, including "the effectiveness of press advertising and other media in direct promotion of the national brand". He also recognises that "the area of study which appears to be missing ... is the relationship between national brand and national culture". This missing area is therefore, is the focus of our research. This paper aims to identify the elements of national culture that contribute to a feeling of national identity among a nation's people in order to identify the essence of a national brand, and to identify the way the national culture is being communicated through that 
national brand. It will do so by examining the case of Poland, a nation with a Soviet past that has recently entered the European Union, and which is attempting to create its own unique brand identity in an increasingly competitive global marketplace.

\section{Culture, Politics and the rise of the Nation State}

Cobban (1969) has traced the growth of the nation state to the middle ages, a time when states were "political entities and there was no belief in any necessary connection between cultural and political ties". However Cobban found that there are opposing views as to what constitutes a nation. One perspective favours definitions based on political unity irrespective of nationality. The opposing conception of the nation is that most favoured by, among others, Herder, the founder of German nationalist thought, who, according to Cobban (1969) was "almost exclusively concerned with the idea of the nation as a cultural entity". Cobban notes that "the modern Western European conception of the nation has largely been a product of the fusion of these two tendencies, combining a measure of free individual choice with a consciousness of the inherited traditions and values of communal life".

\section{National Culture}

Warner and Joynt (2002), researching culture from a comparative management perspective, note that there are two main approaches that are relevant to studies in this area. One approach believes in the concept of divergence (also referred to as contingency in the organisational behaviour literature) that takes an emic stance that management styles should be different because cultures differ from each other. The other approach is convergence, taking the etic stance that management styles should not differ according to culture, especially due to "technology, structure and global 
orientation by many firms" (Warner and Joynt, 2002). This can be seen to relate to the standardisation / adaptation debate that has been waging (unresolved) in the marketing literature since Levitt's seminal paper The Globalization of Markets appeared in the Harvard Business Review in 1983. Given these different approaches Earley and Singh (1995) "suggest that the field integrate its working definitions of nation and culture and create an understanding based on various facets of nations and cultures including economic, legal, cultural and political systems". Child (2002) believes that Max Weber's work offers a "fruitful basis for reconciling ... different perspectives". Weber, "founder of sociology and anthropology" (Salzman, 2001), according to Child (2002), believes "there are dynamic material forces of an economic and technological nature that give rise to efficiency oriented rules and codified knowledge", referred to by Weber as "formal rationality". However, the influence of "substantive values and idealism ... shape 'substantive rationality' which concerns the meaning that people give to social organization ... and is rather more far-reaching than 'culture"". Yet Steger (1998) notes that "globalization is not only an economic phenomenon, but rather includes the contracting role of the nation-state". With recent trends towards globalisation, and developments such as enlargement of the European Union (EU), proponents of the convergence argument claim that "at its strongest it has been suggested that while societies are steadily moving together that the similarities between cultures will become much greater than their differences" (Pugh and Hickson, 2002). Although this argument may appear to be timely given recent EU enlargement, it was first proposed by Kerr et. al. in 1960. Fuchs and Klingemann (2002) believe that "many feel the EU can attain democratic legitimacy only if a European demos with a collective identity takes shape". The authors are concerned that "in view of the cultural plurality and heterogeneity of European nation 
states, it is doubtful whether the constitution of a European demos with a tenable collective identity is possible at all”. Authors such as Williams (1999) believe that for nations such as Wales (within Britain), and Galicia (within Spain), this dilution of distinctive culture and identity has been happening over a much longer period of time. Alternatively, other authors such as Zielonka and Mair (2002) believe an enlarged EU "will be a much more diversified entity following its planned eastward enlargement". They cite elements such as political culture, language, religious beliefs and popular culture as revealing both similarities and differences between cultures. Laitin (2002) does not believe that such generalisations can be made across a newly enlarged EU. He believes that there is a difference between those nations on the periphery of the European Union, particularly those nations joining the EU from Central and Eastern Europe, and nations that are closer to the "continental norm". "Those Europeans whose national cultures are close to the continental norm need only be a member of a single cultural world (2-1); while those Europeans living in 'foreign' European states and those who live in regions of states with state-promoted regional cultures may need to be fully acquainted with three cultural worlds $(2+1)$ ". However, Laitin's perspective that cites English speakers from the United Kingdom as those who need only live in a single (2-1) cultural world, does not recognise the unique cultural and linguistic identities of those within, for example, the Welsh and Scottish statepromoted regional cultures within the United Kingdom. Yet if we evaluate the symbols of these regional cultures such as the "colourful symbols of Scottish identity like the kilt, the bagpipe and whisky, whose association with Scotland is recognised all over the globe, it has to be said that these are ultimately rather superficial manifestations of cultural separateness and hardly compare with, say, language, which, few would deny, constitutes the bedrock of collective cultural identity" 
(Williams, 1999). This reflects Anderson's (1991) view that "from the start the nation was conceived in language, not in blood" therefore, through language acquisition “one could be 'invited into' the imagined community". Laitin (2002) concludes with the interpretation from his study that in such "dynamic national projects (as Europe has become), there is greater interest in promoting a national culture in the periphery than in the centre". He also believes that "the emulation, in seeking to learn English, in wanting secular rule, in listening to 'top ten' songs and watching 'top ten' films ... is a mass phenomenon, belying a notion of cynical adaptation".

Hofstede (2002) is of the opinion that " the way people think, feel and act in many different kinds of situation is somehow affected by the country they are from". Hofstede, however, is a self-confessed pessimist about human society, believing that human mental programming tends a society towards being static and slow to change. Cobban (1969) found that "one of the difficulties of the history of ideas is that names are more permanent than things", so although the country name may remain the same, the cultural symbols of the nation's identity may change, albeit slowly, "according to our concept of what constitutes the 'nation' ... it would appear that people need familiar symbols to feel reassured and even to give shape to their existence" Cameron (1999). As much as a country's culture is slow to change, so therefore is the outsider's perspective of that culture. Leonard (1997) notes, for example, not only that "around the world, ... Britain's image remains stuck in the past" but that "within Britain too, our identity is in transition" with "little consensus about what Britain stands for". 
Cameron (1999) has also found "how difficult it is to define a nation" and asks whether "national identity [is] something of which we ourselves are aware or is it an identity which others bestow upon us?" Cameron asked two young people in their twenties why they felt they were British - answers included holding a British passport, speaking English, and living in Britain. Vincent (1999) conducted work into national identity in the former Eastern Bloc nations of Bosnia and Hercegovina. He found that these nations are also trying to "renegotiate their identities" through the symbols of their cultures. Vincent poses the question "How do people 'tell' who is Serb, Croat, Moslem, or Bosnian?" noting that in areas where ethnicity has become a basis for conflict, the answer to his question can become a vital matter of personal safety. "Rather than saying ethnicity is based in cultural tradition, it might be more appropriate to say cultural tradition is the message an aspiring ethnic group needs to convey - 'that we are people with a valuable tradition'.", stating that this tradition "symbolises the messages that that group want to convey about itself" (Vincent, 1999), and he identified various specific elements of the cultural symbols that may be used to do this: The flag and its symbolic colours used in uniforms etc; styles of dress and particular articles of clothing; language; religion and religious symbols; family names; first names - from “"modern' first names (for example those which imitate those of Western pop stars)" to names that may be seen to be ethnic labels; skin colour; facial hair - e.g. "nowadays someone sporting a big black bushy beard is a Serb"; town of origin; dates; songs; places of meaning; and political identity. From reviewing the various perspectives within the extant literature, we can therefore summarise the elements that are perceived by various authors as being the determinants of national identity (Figure 1), and those elements assumed to communicate this identity through the national brand (Figure 2). 
Figure 1. Determinants of National Identity

\begin{tabular}{|l|l|}
\hline \multicolumn{1}{|c|}{ Author } & \multicolumn{1}{c|}{ Determinants of national identity } \\
\hline Herder (in Cobban, 1969) & $\begin{array}{l}\text { Language } \\
\text { Culture } \\
\text { Political identity }\end{array}$ \\
\hline Cobban (1969) & $\begin{array}{l}\text { Inherited traditions } \\
\text { Values of communal life }\end{array}$ \\
\hline Anderson (1991) & Language \\
\hline Earley and Singh (1995) & Economic systems \\
& $\begin{array}{l}\text { Legal systems } \\
\text { Cultural systems } \\
\text { Political systems }\end{array}$ \\
\hline Cameron (1999) & Cultural symbols \\
& Passport \\
Residence \\
Language
\end{tabular}

Figure 2. Communicators of National Brand

\begin{tabular}{|l|l|}
\hline \multicolumn{1}{|c|}{ Author } & \multicolumn{1}{|c|}{ Communicators of National Brand } \\
\hline Kotler and Gertner (2002) & Geography \\
& History \\
& Proclamations \\
& Entertainment industry \\
& Media \\
& Art \\
& Music \\
& Famous citizens \\
& Other features \\
\hline Anholt (2002) & Culture \\
& Language \\
& Images of popular culture \\
& Creative arts \\
& Tourism and travel writing \\
& Commercial branded products \\
\hline
\end{tabular}




\section{METHODOLOGY}

From the marketing perspective that underpins this research it would appear that the etic, culture-free, standardised convergence approaches are not helpful when seeking to market, brand or promote a country that may attract tourists, economically active immigrant populations, and inward investors, or be able to gain advantages from positive 'country of origin' associations for export goods because of that country's cultural differences from other countries. A more useful method of analysing cultural production and perception in these respects would appear to be from a semiotic study into the meanings the cultural symbols of this nation represent both within and outside of Poland. Within this methodological framework the paper's aims were twofold. Firstly, to identify the elements of national culture that contribute to a feeling of national identity among a nation's people in order to identify the essence of a national brand. In order to do this we surveyed Polish people in Poland. One of the researchers is a native Pole, and so was able to administer the questionnaire in the Polish language. The questionnaire was compiled from the determinants of national identify identified in the literature and indicated in Figure 1, in addition to the specific cultural symbols identified by Vincent (1999). Respondents were asked to rank the extent to which they agreed/disgreed that each determinant contributed to their feeling of 'Polishness' on a 7-point Likert scale. 383 structured questionnaires were returned. $76.8 \%$ of respondents $(n=294)$ were female, $23.2 \%(n=89)$ were male. All respondents were Polish young people aged between 19 and 24, educated to degree standard. This data was then subjected to a frequency analysis in SPSS.

Secondly, we wished to identify the way the national culture is being communicated through that national brand. Some key sources of data already exist to identify the 
way the Polish national culture is being communicated through the Polish national brand. Anholt (2002) believes that travel writing is a relevant data source as it tends "to be more readily believed and accepted when the channel of communication used is itself a cultural artefact, rather than paid for media". Therefore we conducted a semiotic analysis of all 40 articles published in the travel sections of UK broadsheet newspapers over the two-year period between January $2003-2005$. The analytical framework was determined from those elements identified in the literature as the communicators of national identity indicated earlier in Figure 2. Turner (1990) believes that, "while it is not entirely scientific, semiotics ... has become a most useful method" for the study of culture and the meanings of the cultural product. This is a view shared by, among others, the renowned culture theorist Clifford Geertz, "founder and advocate of interpretive anthropology, also known as symbolic or semiotic anthropology" (Salzman, 2001). While "the Weberian theory as elaborated by Parsons analysed the integrated human system of action into three analytic subsystems" (Salzman, 2001), namely social, personality and cultural, Geertz "was interested particularly in Parsons' cultural subsystem" (Salzman, 2001) consisting of the symbols a culture creates and offers to the world.

This research was supplemented by the findings from two group interviews conducted in order to gain deeper insight into non-Polish people's perceptions of Poland. In total the groups comprised 10 respondents, MBA students from overseas, studying in the UK, who were about to embark on a study trip to Poland. None had ever visited Poland previously. 7 respondents were male, 3 female. 3 were from Africa, 2 each from India and Pakistan, and one each from Canada, Mauritius and Malaysia. The data gained from each focus group was transcribed in full. In order to increase validity 
of the findings, each researcher analysed the newspaper articles and transcripts of the focus groups separately in order to identify indicative findings. Both researchers' interpretations of each dataset were in agreement.

\section{FINDINGS}

\section{Determinants of national identity}

Survey results are presented in Table 1. By using a 7-point scale clustering around the mid-point did not occur.

Table 1: Contributors to a feeling of national (Polish) identity

\begin{tabular}{|l|l|l|l|l|l|l|l|l|}
\hline & $\begin{array}{l}\text { Strongly } \\
\text { agree }\end{array}$ & $\begin{array}{l}\text { Mildly } \\
\text { agree }\end{array}$ & Agree & Neither & Disagree & $\begin{array}{l}\text { Mildly } \\
\text { disagree }\end{array}$ & $\begin{array}{l}\text { Strongly } \\
\text { disagree }\end{array}$ & $\begin{array}{l}\text { No } \\
\text { response }\end{array}$ \\
\hline I speak Polish & 269 & 83 & 15 & 7 & 5 & 1 & 1 & 2 \\
\hline $\begin{array}{l}\text { I live in } \\
\text { Poland }\end{array}$ & 277 & 75 & 17 & 5 & 5 & 1 & - & 3 \\
\hline $\begin{array}{l}\text { I have Polish } \\
\text { nationality }\end{array}$ & 280 & 69 & 17 & 9 & 4 & - & 1 & 3 \\
\hline $\begin{array}{l}\text { I have Polish } \\
\text { parents }\end{array}$ & 282 & 74 & 16 & 5 & 2 & 1 & 1 & 2 \\
\hline $\begin{array}{l}\text { My family } \\
\text { name is Polish }\end{array}$ & 224 & 76 & 30 & 23 & 1 & 9 & 7 & 3 \\
\hline $\begin{array}{l}\text { My first name } \\
\text { is Polish }\end{array}$ & 204 & 67 & 37 & 29 & 19 & 12 & 13 & 2 \\
\hline \begin{tabular}{l} 
I look Polish \\
\hline \begin{tabular}{l} 
Polish flag \\
\hline
\end{tabular}
\end{tabular} & 209 & 98 & 51 & 10 & 8 & 1 & 3 & 3 \\
\hline $\begin{array}{l}\text { National } \\
\text { colours }\end{array}$ & 179 & 115 & 52 & 17 & 4 & - & 3 & 3 \\
\hline $\begin{array}{l}\text { National } \\
\text { anthem }\end{array}$ & 237 & 77 & 35 & 11 & 10 & 1 & 4 & 8 \\
\hline $\begin{array}{l}\text { Patriotic } \\
\text { songs }\end{array}$ & 74 & 99 & 108 & 55 & 29 & 9 & 8 & 5 \\
\hline $\begin{array}{l}\text { Observing } \\
\text { historic dates }\end{array}$ & 135 & 110 & 74 & 33 & 21 & 1 & 4 & 5 \\
\hline $\begin{array}{l}\text { Understanding } \\
\text { history/culture }\end{array}$ & 117 & 142 & 71 & 30 & 13 & 2 & 3 & 5 \\
\hline $\begin{array}{l}\text { Keeping } \\
\text { traditions }\end{array}$ & 185 & 121 & 46 & 12 & 9 & 2 & 4 & 4 \\
\hline $\begin{array}{l}\text { Catholic } \\
\text { religion }\end{array}$ & 133 & 105 & 64 & 36 & 12 & 14 & 14 & 5 \\
\hline $\begin{array}{l}\text { Contributing } \\
\text { to Poland }\end{array}$ & 47 & 82 & 100 & 91 & 29 & 16 & 4 & 4 \\
\hline
\end{tabular}


Given the accession of Poland to the European Union in May 2004, survey respondents were also asked whether, in the near future, they believed they would see themselves as primarily Polish or European (Table 2). This question is also asked of individuals from EU member states on a periodic basis by the Public Opinion Analysis sector of the European Commission.

Table 2: Perceptions of future identity

\begin{tabular}{|l|r|r|}
\hline $\begin{array}{l}\text { In the near future I am likely to see } \\
\text { myself as... }\end{array}$ & $\%$ & $\mathrm{n}=$ \\
\hline Polish only & 11 & 42 \\
\hline Polish first, then European & 80 & 304 \\
\hline European first, then Polish & 7 & 29 \\
\hline European only & 1 & 5 \\
\hline
\end{tabular}

\section{Perceptions of the national brand outside the nation}

Focus group responses were then analysed to identify not only what our respondents

knew and perceived about Poland, but also how they came to gain this knowledge and form such perceptions. Initial responses centred around factual information, such as knowing what currency was used in Poland, the weather - "I know it's cold", and what language is spoken "we know they speak Polish", although one 26 year old Indian male did have to check this with the other respondents. One respondent commented, "I met some Polish people and they are very weak in English, that's what I know ...they cannot speak English, we cannot speak Polish”. Further responses also referred to religion, with respondents identifying Poland as a Catholic country, and identifying it as the country of origin of Pope John Paul II. Respondents also mentioned food and drink. "I know that the potato is a very important dish over there". "Poles like to drink; I know that. They like vodka", and that "I know that they make the best vodka in the world, or the second best with the Russians; they are pretty much the best." 
As noted earlier, these respondents are MBA students who were about to embark on a study trip to Poland during which they would also visit the Auschwitz concentration camp, prompting the comment from one respondent that "Auschwitz ... is that kind of place that you have to see". Another respondent made the following comment:

"There is a concentration camp there, I've read about it before previously some years back... it's popular because there was a popular Catholic saint, Maximillian Kolbe, he was killed there. I'm Catholic so that's how I read about that. I'm looking forward to going to Auschwitz, because we will be going there. That's all I know about Poland."

Some respondents were also familiar with Poland's Soviet past, the rise of trade unionism, subsequent break from communism, and entry into the European Union. “They've been invaded by Russia... and after the Second World War they were under the influence of the communists for many years. They recently, I don't know... few years ago they have their freedom back". Another respondent commented that "they were sometime the forefront of trade unionism, you know with that trouble started in Gdansk, was is with Waleski [sic], who became the president ...the Polish are looked on as democratic, you know, that is where they broke free from the pressures of the former East". However, despite EU accession happening eight months previously in May 2004 one respondent did not think that this had taken place yet. "They are going to be a part of the EU... it's just a matter of time. " Other perceptions about Poland concerned the current nature of the economy, described by respondents as "developing” and "emerging”. Knowledge concerning EU accession, and subsequent economic migration also prompted this comment from one respondent concerning Polish education and employment opportunities.

"From what I could gather there are lots of people who are unemployed there and they are shifting to London and other parts of Europe to look for jobs... they are more, like, looking for jobs that don't require, like in a company, they are just manual operational jobs, and lots of them are doing that actually in the UK, so I don't know if there is much education there". 
Responses were also forthcoming concerning the Polish national character. Common perceptions within both focus groups were that Polish people "are all hard workers", “they wouldn't like to leave any stone unturned in my experience, so whatever you ask is accomplished". Common perceptions were that while they are "friendly", Poles are also "reserved", "quiet" and "calm", "not people that are eccentric like the New Yorker for example that is very loud". One respondent believes that these character traits may be traced back to:

"The historical background of Poland and other Eastern European countries, ... they have been suppressed ... they are still cowering ... I think they still live in the culture of fear, you know, that they are not totally away from their former selves."

Respondents also noted that their perceptions would be coloured to some extent by their own country of origin.

"I come from India and in India you will find people from each and every part of the world, but I've never come across a person from Poland. So that shows how reserved they are maybe in their culture or the communities."

A respondent from Ghana stated "we may even be tempted to say that we are more civilised, more open than them, looking at it from this view. I have a background back home, and that is why I am bringing that kind of background here, so when I see a Polish I think I am more civilised than he is".

I think that probably Poles pushed away Russians; there will be the Russian influence ... if you go to Quebec, for example, where I'm from, we are a minority and the Canadians always try to influence, but also take over us, but French Canada always resists. And I think Poles are the same, they always resisted Russians, I think they kept their own identity and their own... I don't think we will see so much of... there might be a bit of Russian influence... maybe their vodka comes from that? I don't know.

Respondents noted that they had gained such knowledge and formed such perceptions about Poland from meeting Polish people or being exposed to information about Poland either through work or socially, (one respondent having had a Polish girlfriend for a short time); through their studies, "we were doing a project on South African 
brewery and Polish market is really coming out as really big"; through "reading"; " $T V$ "; and "the internet". Some respondents also commented on the lack of information sources concerning Poland. "There's not much ... advertisement where there's much talk about Poland I would say that you would be interested in anyway." "Maybe it's an interesting place”, "But ... people are not aware of it."

\section{Communicators of national brand}

The results of analysing the 40 articles on Poland from the travel sections of UK broadsheets published between January 2003 - 2005 are presented in Table 3, where n $=$ the number of articles that mention each brand communicator.

The analytical framework was determined from those elements identified in the literature as the communicators of national identity indicated earlier in Figure 2, which includes culture as a very general term. Therefore the cultural references within each article were analysed to determine the communication of specific cultural indicators also identified in the extant literature.

Other communicated features falling outside of these categories were food $(n=18)$, particularly peirogi - savoury dumplings with different fillings $(n=10)$, cabbage $(n=$ 5), beetroot soup $(n=5)$ and potatoes $(n=5)$; drink, especially vodka $(n=11)$ and beer $(n=8)$; Poland's recent accession to the EU $(n=16)$; and Poland's diverse architecture $(\mathrm{n}=28)$ including places of potential tourist interest such as castles, museums, and historic monuments. 
Table 3: Poland: What is communicated

\begin{tabular}{|c|c|c|}
\hline Communicator & $\mathrm{n}=$ & Comments \\
\hline $\begin{array}{l}\text { Culture } \\
-\quad \text { Language }\end{array}$ & 8 & $\begin{array}{l}\text { Polish }(\mathrm{n}=7) \text {; Esperanto }(\mathrm{n}=1) \text { as a "thriving Esperanto community lives } \\
\text { in Bialystok" birthplace of the language's inventor Ludwik Zamenof. }\end{array}$ \\
\hline - Appearance & 4 & $\begin{array}{l}\text { References included "big men with traditional Polish moustaches, wearing } \\
\text { check shirts" }(\mathrm{n}=1) \text { and the "henna mullet - still a favourite among east } \\
\text { European womanhood" }(\mathrm{n}=1) \text {. }\end{array}$ \\
\hline - $\quad$ Key dates & 2 & $\begin{array}{l}\text { "May Day"; the "60th anniversary of the liberation of Auschwitz"; and } \\
\text { 27th January, "Holocaust Memorial Day" were mentioned. }\end{array}$ \\
\hline - $\quad$ Religion & 18 & Catholicism $(n=16)$ and Judaism $(n=15)$ were both mentioned. \\
\hline Geography & 24 & $\begin{array}{l}\text { Articles mentioned geographic elements such as scenery }(\mathrm{n}=16) \text {; the } \\
\text { Tatra }(\mathrm{n}=6) \text { and Carpathian mountains }(\mathrm{n}=3) \text {; Poland's forests }(\mathrm{n}=9) \text {, } \\
\text { especially the Bialowieza forest }(\mathrm{n}=7) \text {, a protected reserve "compared to } \\
\text { primary Amazon rainforests" situated on the Belarus border; Poland's } \\
\text { flora }(\mathrm{n}=10) \text { and " } 12,000 \text { species of fauna" }(\mathrm{n}=12) \text {, especially the } \\
\text { existence of "all but one of the European mammals". }\end{array}$ \\
\hline $\begin{array}{l}\text { History } \\
-\quad \text { General }\end{array}$ & 22 & $\begin{array}{l}\text { Articles ranged from mentioning the legend of the forefathers of the three } \\
\text { Slav nations - Lech, Czech and Rus - who met after many years apart and } \\
\text { decided to build a town and call it Poznan thereby forming the Polish state; } \\
\text { the Hejnal trumpet call sounded by a bugler at St Mary's Basilica - } \\
\text { commemorating } 1241 \text { when a bugler tried to warn of an impending attack } \\
\text { by the Tartar army; Poland's medieval royal past and the six centuries } \\
\text { when dukes and kings of Poland lived in Wawel Castle and Poland was a } \\
\text { "leading European power" before being "divided between Russia, Austria } \\
\text { and Prussia", regaining its independence in 1918, and later being } \\
\text { "gobbled up by Hitler and Stalin". }\end{array}$ \\
\hline - WW II & 26 & $\begin{array}{l}\text { Specific reference was made to the "almost total destruction of Warsaw by } \\
\text { the Nazis" }(\mathrm{n}=8) \text {; concentration camps }(\mathrm{n}=6) \text {; and Prisoner Of War } \\
\text { camps }(\mathrm{n}=3) \text {. }\end{array}$ \\
\hline - $\quad$ Soviet past & 27 & $\begin{array}{l}\text { Many general references, with specific reference to the mark it made on } \\
\text { Poland's city architecture, such as the Palace of Culture and Science ( }= \\
\text { 9) in Warsaw, "Stalin's fifties 'gift' to the Poles". }\end{array}$ \\
\hline Entertainment & 9 & $\begin{array}{l}\text { The following films were mentioned: Schindler's List }(\mathrm{n}=6) \text { filmed in } \\
\text { "Kazimierz - Krakow's ancient Jewish quarter"; The Great Escape }(\mathrm{n}= \\
\text { 2); The Wooden Horse }(\mathrm{n}=1) \text {, and Roman Polanski's The Pianist }(\mathrm{n}=1) \text {, } \\
\text { all of which are set during World War II in Poland. }\end{array}$ \\
\hline Art & 5 & $\begin{array}{l}\text { Fresco's in Wawel castle by Hans (brother of the more famous) Albrecht } \\
\text { Durer; Leonardo's 'Lady with an Ermine' in the Czartoryski gallery }(\mathrm{n}=2) \text {; } \\
\text { the Black Madonna of Czestochowa }(\mathrm{n}=2) \text { "reputedly painted from life by } \\
\text { St Luke"; and the 16th century frescos in the bedrooms of the Hotel } \\
\text { Copernicus. }\end{array}$ \\
\hline Music & 10 & $\begin{array}{l}\text { One article noted that Krakow is "an intensely musical city", another that } \\
\text { in Warsaw "productions of classical music, ballet and opera are nightly } \\
\text { occurrences", yet another mentioned "Jewish klexmer music", but in the } \\
\text { main, articles concentrate don mentioning jazz }(\mathrm{n}=4) \text {, Chopin recitals and } \\
\text { the annual Chopin Festival }(\mathrm{n}=3) \text {, and the Zakopane International Festival } \\
\text { of Highland Folklore }(\mathrm{n}=2) \text {. }\end{array}$ \\
\hline Famous citizens & 19 & $\begin{array}{l}\text { The most frequently occurring reference was to Pope John Paul II }(\mathrm{n}=9) \text {; } \\
\text { Chopin }(\mathrm{n}=6) \text {; Nicolas Copernicus }(\mathrm{n}=6) \text {; Lech Walesa }(\mathrm{n}=2) \text {; Marie } \\
\text { Curie }(\mathrm{n}=2) \text {; Ludwig Zamenof }(\mathrm{n}=1) \text {; Wojciech Fibak, the former tennis } \\
\text { player }(\mathrm{n}=1) \text {; Czeslaw Milosz, the Nobel Prize-winning poetry and prose } \\
\text { writer }(\mathrm{n}=1) \text {; Oskar Schindler }(\mathrm{n}=1) \text {; poet Adam Mickiewicz }(\mathrm{n}=2) \text {; } \\
\text { poet Wieslawa Szymborska }(\mathrm{n}=1) \text {; film maker Andrzej Wajda }(\mathrm{n}=1) \text {; } \\
\text { Klaus Kinski }(\mathrm{n}=1) \text {; and "grand master of science fiction prophecy" } \\
\text { Stanislaw Lem. }\end{array}$ \\
\hline
\end{tabular}




\section{Discussion}

It was evident from the outset that, in order to explore the relationship between national brand and national culture fully (Anholt, 2002), it would be necessary to examine literature from a range of academic disciplines. Our study concurs with earlier findings (for example Cobban, 1969; Gellner, 1983; Anderson, 1991) evidencing the link between national, political and cultural identity, and with the Weberian perspective that such a subject could best be studied by combining a range of approaches (Earley and Singh, 1995) examining both formative and substantive rationalities. Our aims were to examine the distinctiveness of the brand of Poland, to find out what contributes to a feeling of Polishness among Polish people, to examine the way that the brand was communicated and perceived outside of the nation, and to find out how these perceptions were formed. Williams (1999) noted the recent dilution of a number of national cultures leading to a lack of distinctiveness. This is very pertinent to our study given Poland's history having been ruled variously by Polish medieval kings, Austrians, Prussians and Russians, having been invaded by Nazi Germany during World War II, subsequently falling to Soviet rule, and most recently gaining national freedom and joining the European Union.

Although earlier studies have identified a range of indicators of national and cultural identity, i.e. what elements contribute to a feeling of identity amongst individuals within a nation, the findings from our survey have begun to suggest that certain elements may contribute more than others. Both Anderson (1991) and Williams (1999) believe than language is a key indicator of such identity, this was also found to some extent in our analysis of travel writing and focus group responses. However one does not become Polish simply by speaking the language, thereby being "invited in to 
the imagined community" as posited by Anderson, although this was agreed to some extent as contributing to their feelings of Polishness by $96.3 \%$ of our survey respondents $(n=367)$. A feeling of Polishness is to be gained from having Polish parents, $(97.6 \%$ of respondents, $\mathrm{n}=372)$; living in Poland $(97.1 \%, \mathrm{n}=369)$; and holding Polish nationality $(96.3 \%, \mathrm{n}=366)$. Vincent's (1999) study into national identity in Bosnia and Hercegovina identified a number of cultural symbols including national flags, colours, anthems and traditions. The Polish flag was agreed to contribute to a feeling of Polishness by $94.2 \%$ of survey respondents $(n=358)$; the national anthem by $93.1 \%(\mathrm{n}=349)$, keeping Polish traditions and habits by $92.9 \%(\mathrm{n}$ $=352)$, and the Polish national colours by $91.1 \%(n=346)$. Focus group respondents did not mention any of these symbols. Polish traditions and habits were not generally mentioned in the newspaper articles, except for example the Hejnal trumpet call sounded from the tower of St. Mary's Basilica. These articles offer no real insight into Polish customs, habits and way of life. Understanding Polish history and culture was agreed as a contributing factor by $87.3 \%$ of respondents $(n=330) .22$ articles mentioned Poland's past in general terms. Auschwitz was mentioned by focus group respondents, and also referred to in 6 articles. World War II was mentioned in general terms in 26 articles, and in each of the 9 films mentioned about Poland. The nation's soviet past was also mentioned by focus group respondents and in 27 articles. These can be seen to be determinants of national identity that could be construed from either a cultural or political perspective (see Cobban, 1969). They also evidence the huge changes Poland has faced in its recent history. Although it is generally held that perceptions of a nation can only change slowly (Cobban 1969; Leonard 1997; Hofstede 2002), it appears from analysing articles and focus group responses that there has been a change in perceptions of Poland in a relatively short time. 
Vincent (1999) also identified the following cultural traditions that any aspiring ethnic group needs to convey. Observing historic national dates was agreed as contributing to a feeling of Polishness by $84.4 \%$ of respondents $(n=319)$ but was not mentioned in either focus group, and only mentioned in 2 articles. Another symbol agreed as a contributor by survey respondents was having a Polish family name $(86.8 \%, \mathrm{n}=330)$, as was having a Polish first name $(80.8 \%, \mathrm{n}=308)$, yet neither symbol featured in in newspaper articles except when discussing a conversation or interview with a named Pole, and were not mentioned in focus groups. Patriotic songs were agreed to contributing to a feeling of Polishness by $74.3 \%$ of survey respondents $(n=281)$, but there were no references to this in either focus group, nor in any article. The Catholic religion was agreed as a contributor by $79.9 \%$ of survey respondents $(n=302)$, was also mentioned in both focus groups and was mentioned in 16 of the 40 newspaper articles. Although identified in the literature as a cultural indicator, religion is also seen to have become somewhat politicised in Poland in a stand against anti-religious communist oppression. Looking Polish, agreed as contributing to a feeling of Polishness by $73.9 \%$ of survey respondents $(n=280)$, although offering a significant indicator in Vincent's (1999) work was not mentioned in either focus group, and there were only 4 references to appearance in newspaper articles. Making a contribution to Poland was agreed as a contributor by $60.4 \%$ of survey respondents $(n=229)$. Poland's famous citizens were often mentioned in the articles $(\mathrm{n}=19)$ and also within both focus groups. Although not referenced in the literature, food and drink can be seen to be relatively culturally specific. Food, especially potatoes, was mentioned by the focus group respondents and also mentioned in 5 articles. Vodka was mentioned in both focus groups and in 11 articles. 
Our findings therefore evidence significant gaps between what Polish people feel contributes to their sense of distinctive identity or national brand, what is communicated about this identity or brand, and what is perceived as the national brand by those outside of the nation. Focus group responses also appear to have validated the emic perspective that underpinned this study, by noting that respondents' perceptions of Poland would be coloured by their own cultural background. These perceptions also seem to be linked to how they found out information about Poland upon which to base their perceptions. For example, a focus group respondent assumes low levels of education and employment in Poland from having met and heard about Polish people looking for low-level work in EU countries. In the main our respondents mostly found out information from personal experience, having worked with Poles, through projects and other studies, or through communications channels such as TV and the internet.

When analysing communicators of the nation brand we found evidence of most of the indicators mentioned by Kotler and Gertner (2002), and Anholt (2002). Here we also found that certain elements may contribute more than others. Historical references were the most frequently occurring, next general cultural references, then geographic. Music, entertainment and art were mentioned less frequently.

Laitin (2002) believes that the Central and Eastern European nations differ greatly from those in Western Europe. He also believes these peripheral nations are more interested in promoting national culture than those closer to the central "continental norm" of the EU, yet our focus group respondents noted the lack of such promotion. Accession to the EU was mentioned in the focus groups and in 16 articles. Survey 
respondents believed that, in the near future, only $11 \%(n=42)$ would see themselves as Polish only, yet $80 \%$ of respondents $(n=304)$ believe they would see themselves as Polish first, then European. This is evidence of further change for Poland, and one that will bring about more challenges for its future as a full member of the European Union. Cameron (1999) identified the difficulty of defining what constitutes a nation, yet Kotler and Gertner (2002) stress the importance of creating a distinctive and positive identity for the destination brand that is capable of gaining and maintaining competitive advantage in the global marketplace. Morgan, Pritchard and Pride (2002) found that some nations have underdeveloped identities, and are not always generally perceived as brands. We have found that what is perceived about a nation brand is linked to how this perception is formed, and that these perceptions are often made from personal contact with individuals from that nation. This can provide valuable insight to the various stakeholders involved with managing and promoting the national brand that could help them understand the importance of their role in the brand creation system. We have also begun to identify the specific links between national brand and national culture, and have found that certain elements of national culture appear to play a more important role than others. However, in order to generalise our findings, further research would need to be done to test the findings from this study in other countries, and within various ethnic groups within a nation.

\section{REFERENCES}

Anderson, B. (1991) Imagined Communities: Reflections on the Origin and Spread of Nationalism, Revised Edition, Verso, London and New York

Anholt, S. (2002) "Foreword”, Journal of Brand Management, Apr2002, 9(4/5)

Cameron, K. (ed.) (1999) National Identity, Exeter: Intellect Books

Cobban, A. (1969) “The nation state and self-determination”, London: Fontana 
Fuchs, D. and Klingemann, H-D., "Eastward Enlargement of the European Union and the Identity of Europe" in Mair, Peter, and Jan Zielonka (eds) (2002) "The Enlarged European Union: Diversity and Adaptation”, London: Frank Cass publishers

Gellner, E. (1983) Nations and Nationalism, Cornell University Press, Ithaca

Kotler, P. and Gertner, D. (2002) "Country as brand, products, and beyond: A place marketing and brand management perspective", "Journal of Brand Management", Apr2002, 9(4/5)

Laitin, David "Culture and national identity: 'The East' and European integration", In Mair, Peter, and Jan Zielonka (eds) (2002) "The Enlarged European Union: Diversity and Adaptation", London: Frank Cass publishers

Mair, Peter, and Jan Zielonka (eds) (2002) “The Enlarged European Union: Diversity and Adaptation”, London: Frank Cass publishers

Pugh, D.S. and Hickson, D.J. (2002) "On organisational convergence" in Warner, M. and Joynt, P. (2002), (eds.) Managing across cultures: Issues and perspectives, $2^{\text {nd }}$ Edition, London: Thomson Learning

Vincent, J.A. (1999) "Symbols of nationalism in Bosnia and Hercegovina", in Cameron, K. (ed.) (1999) National Identity, Exeter: Intellect Books

Warner, M. and Joynt, P. (eds.) (2002), Managing across cultures: Issues and perspectives, $2^{\text {nd }}$ Edition, London: Thomson Learning

Zielonka, Jan and Peter Mair "Introduction: Diversity and adaptation in the enlarged European Union" in Mair, Peter, and Jan Zielonka (eds) (2002) "The Enlarged European Union: Diversity and Adaptation”, London: Frank Cass publishers 